\title{
The Development Strategies of China's IT Enterprises in the Post Financial Crisis Era
}

\author{
LIU Xi-yang \\ School of Management \\ Shanghai University \\ Shanghai, China \\ e-mail: xixi_dancer@163.com
}

\author{
DAI De-bao \\ School of Management, \\ Shanghai University \\ Shanghai, China \\ e-mail: ddb@shu.edu.cn
}

\begin{abstract}
The international financial crisis swept the whole world in 2008, not only had a huge impact on the global financial and economic, but also caused varying degrees of impact on all walks of life. As one of the most rapid development industry, IT industry has also inevitably affected by the invasion. Through the study of the impact of the financial crisis on China's IT industry and the SWOT analysis of Chinese IT companies in the post-crisis era, then proposed that in the post-crisis era China's IT enterprises need to make appropriate adjustments and implement relative strategies. In response to the crisis should grasp the opportunities and challenges brought by the crisis and improve their resistance to the crisis and the ability to resist risks, these will benefit the development of the IT industry and improve the competitive advantage of IT companies.
\end{abstract}

\section{Keywords-financial crisis; IT; SWOT; strategies}

\section{INTRODUCTION}

Since the second half of 2008 , severely affected by the spread of the international financial crisis, the world's major economies experienced another shock after the Second World War. In the role of the national government introduced a series of economic stimulus policies, since the second quarter of 2009, although the unemployment rate is still higher, the world ec onomy has been getting better, global economic confidence is gradually restored, economic leading indicators of PMI (manufacturing purchasing managers' index) is picked up, industrial real output began to pick up, the spreads indicators of the financial market recovery normal, consumers' confidence shocks rebounded, economic growth is expected to increase, the glo bal economy has been gradually through the panic of the financial crisis into the "post-crisis era" [1].

The post-financial crisis era means that the easing of the crisis, and the emergence of a relatively stable state. But this stable is relatively, because the root of the crisis has not been eliminated, and the crisis does $\mathrm{n}$ ot end. So the world economy still has a lot of uncertainties. The economic crisis may come back at any time and lead to a new round of recession.

\section{SWOT ANALYSIS ON THE POST-FINANCIAL CRISIS ERA OF CHINESE IT COMPANIES}

In the post-crisis era, there are a variety of favorable and unfavorable factors in Chinese IT companies. At the same time, in the aftermath of the crisis, there are also a variety of opportunities and challenges for Chinese IT co mpanies (Figure 1).

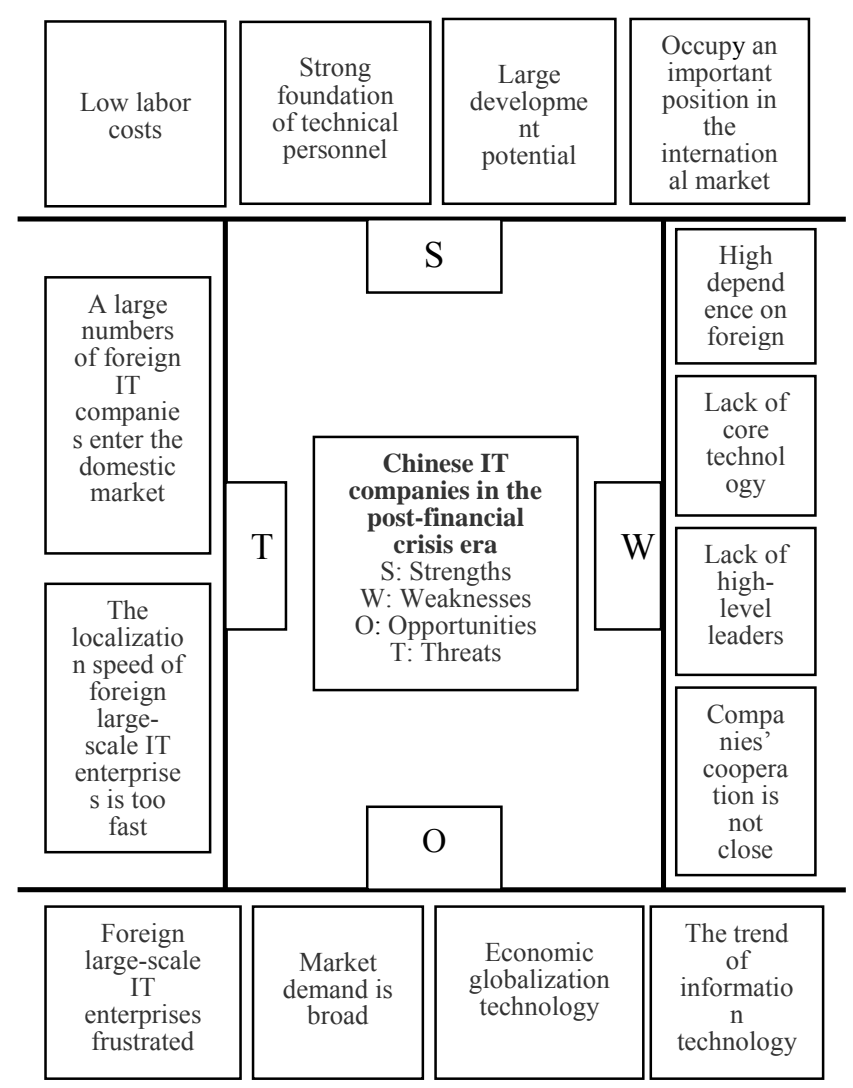

Figure 1. SWOT analysis on the post-financial crisis era of Chinese IT companies

\section{A. Strength}

1) Low labor costs: China is a big country of human resources, compared other developed countries, China's labor cost is very low. Europe and the Unit ed States I T enterprises have to choose layoffs to "spend the winter" when they are facing the crisis, while this pressure of Chinese IT enterprise is much smaller, this is a ve ry favorable competitive advantage [1]. 
2) Strong foundation of technical personnel: So far, the quantity of Chinese IT enterprise is more and more, and the possession of market share is growing. When facing the increasingly powerful IT industry, more and more people choose to devote to this industry. This makes the Chinese IT enterprises gathered a lot of talent, and have a s trong technical basis [2].

3) Large development potential: From the product life cycle theory, the current IT industry of China is still in the growth stage, this is different from Europe and the United States IT industry. In a ddition China's IT product consumption is far lower than the United States and other developed countries, the market of our country is still far from reaching saturation state, there is very great development potential in the future.

4) Occupy an important position in the international market: China's IT industry matures gradually, and at the same time IT enterprises are gradually strong, and they have begun to enter the world market. In 2011, like HUAWEI, Lenovo, Foxconn technology, Acer and other IT enterprises have entered the world 500 list. And compared with 2010, ranking has increased overall, accounting for market share continues to expand. And like Alibaba, Baidu and other non manufacturing IT enterprises, also gr adually open the international market, and have achieved considerable success. Visible, China's IT enterprise's development situation is very good [3].

\section{B. Weaknesses}

1) High dependence on foreign: In $\mathrm{f}$ act China's IT industry is a very high ratio of dependence on foreign trade. A big part o $\mathrm{f}$ capital, market and job opportunities are provided by the international IT companies. Like HUAWEI, ZTE and other enterprises, the largest sales market is abroad. And as some of the IT manufacturing enterprise, such as Foxconn, etc., most of the products are exported for large international IT enterprise. Therefore, Chinese IT enterprises are susceptible to the international market, and when the fin ancial crisis comes, Chinese IT enterprise will be affected certainly [3].

2) Lack of core technology: Compared with the IT enterprises in developed countries, Chinese IT enterprise's core technology is relati vely less, most still rely on the international advanced technology. This makes the Chinese IT enterprises lack of core competitiveness in facing the crisis.

3) Lack of high-level leaders: Chinese IT industry lacks of high-level scientific leaders and research leaders. This will result in the face of difficulties and crisis, some enterprises will appear the situation that leadership is insufficient and direction is unknown.

4) Cooperation between enterprises is not close: Although there are more and more IT enterprises appear in all kinds of fields in o ur country, but the cooperation of these enterprises is very poor, personnel advantage can't situation together. In the face of crisis comes, we can't effectively condensed into effective force, but individually combat, this makes the difficulty of resolving the crisis.

\section{Opportunities}

1) Foreign large-scale IT enterprises frustrated: Due to the international financial crisis, the IT in dustry of Europe and the United States inevitably suffered a great blow. They will enter a period of rest. But this period for China's IT industry will be a very good time. Because of the impact of China's IT industry was not as big as IT enterprise in Europe and the United States, so we can catch th e chance, form a powerful army, then occupy the market successfully.

2) Market demand is broad: After the financial crisis, all walks of life will constantly adjust and change strategies in order to pass through the crisis smoothly. It is a favorable opportunity for Chinese IT enterprises to enter the all walks of life. At the same time, China's economy is in is in the stage of industrialization, market demands are very board.

3) Economic globalization.

4) The trend of information technology: In the present era, economic globalization has become a trend. It al so makes the information become an inevitable trend. IT enterprise with high technology, high information features makes it become one of the most powerful competitors in this trend.

\section{Threats}

1) A large numbers of foreign IT companies enter the domestic market: Due to the international financial crisis, large foreign IT enterprise will further strengthen and enhance market competitiveness after the reshuffle. For the Chinese market which occupies an important position in the world IT consumer market, it will face stronger competition from international IT enterprises. IT companies frustrated In the European and American market will definitely put a business focus to China and other emerging market and some less a ffected markets. They have been in China an $\mathrm{d}$ other countries, and build companies and research institutes. These market in is the space for Chinese IT co mpanies survive and develop. When we face the same strategy that the international manufacturers take, the advantages of low cost and low price for China will not be exist. The d irect influence by financial crisis on China's IT industry and IT manufacturers is that the competition will be more intense and cruel, so enterprise who lack of competitiveness is likely to be merged or self out [4].

2) The localization speed of foreign large-scale IT enterprises is too fast: Relative in Chinese IT Enterprises, because these enterprises have more advanced technology and more intensive capital, and they have a better brand effect, these advantages for Chinese IT en terprises which are not mature enough, is a huge threat and challenge. 


\section{THE DEVELOPMENT STRATEGIES OF CHINA'S IT ENTERPRISES IN THE POST-FINANCIAL CRISIS ERA}

In the face of the economic crisis with both opportunities and challenges, after the crisis, China's IT enterprises need to keep their own advantages but also take the time to adjust and transform the strategy. This can $\mathrm{n}$ ot only successfully recovered from the crisis, and be able to i mprove their competitive power, so as to achieve better development. Therefore, the development strategies of China's IT enterprises in the post financial crisis era are show $n$ in Figure 2 and Figure 3.

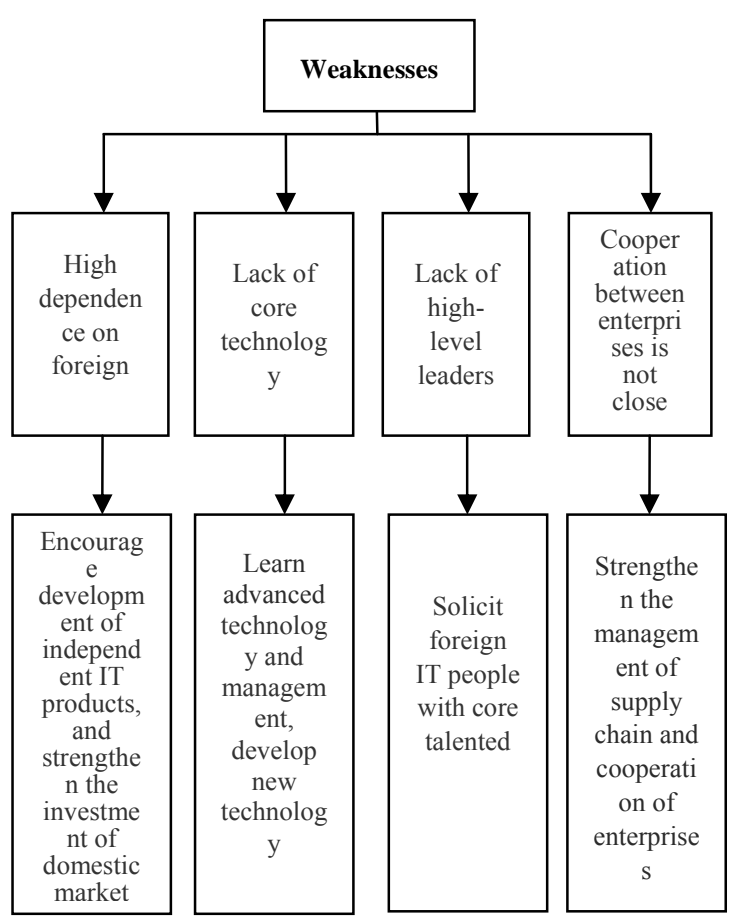

Figure 2. Weaknesses and Coping Strategies

Specifically, the Chinese IT enterprises could adjust and reform by the following aspects.

First, in the c ontext of the post-crisis era, in order to reduce China's dependence on foreign IT companies, first of all, we should adjust the strategies of Chinese IT enterprises. IT strategy should around the change of enterprise strategic [5]. In the strategy of adjustment process, enterprise should build the determination and confidence of using IT applications, we can adopt the following strategies: 1 . Encourage independent intellectual IT products development, increase the support for original IT products, continue to focus on development frontier of domestic IT industry. Increase the investment in the domestic market. At the same time, we should a lso reduce the outsourcing of foreign IT enterprises; 2. Promote the new media and new culture industries to support the de velopment of the IT industry; 3 . To strengthen the co st management, we can't take extensive management like before, but require meticulous management, reduce management costs.

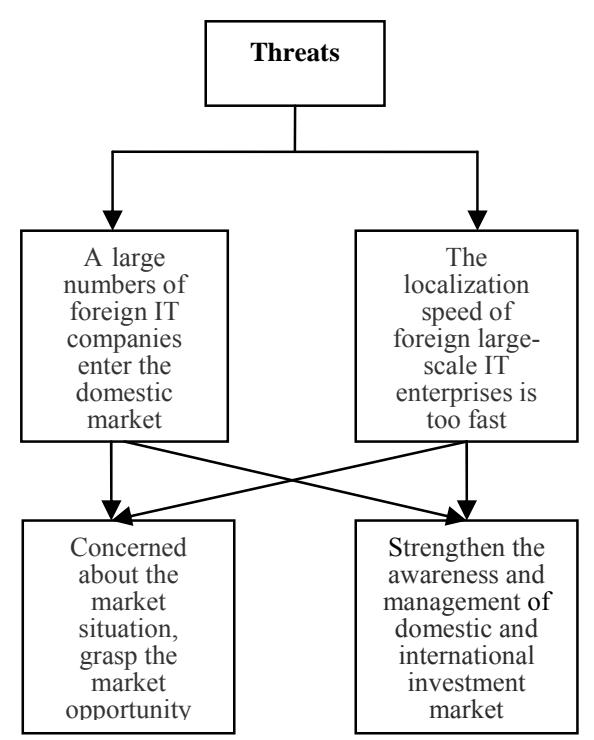

Figure 3. Threats and Coping Strategies

Second, we should solicit foreign IT peop le with core talented. Affected by the ec onomic crisis, a large numbers of IT companies in Europe and America have laid off employees to save capit al. With the IT industry of Europe and the United States set off a layoff storm, the number of circulating of high-end IT $t$ alent is increasing. For the Chinese IT industry which is walking towards the world at present, it is a rare opportunity to recruit the world's top IT talent.

The third is to strengthen the enterprises' supply chain management and improve contact with the IT industry on the Upstream and downstream markets in the longitudinal direction. In the upstream market, improve the contact with electronic industry, encourage the combination of IT technology and electronic communication, actively introduce high-tech electronic products in order to $f$ orm partnerships[6]; in the downstream market, strengthen the linkages of software and hardware sale $s$ markets and internet service market. By strengthening enterprises' supply chain management, so as to improve their own status in the industrial chain, strengthen the co mpetitive advantages.

The fourth is to pay attention to the changes in market structure, and mine business opportunities of the market. In the domestic market, due to the international financial crisis and the trend of economic globalization, more and more international IT companies enter the Chinese market, domestic manufacturers should strengthen cooperation with the international IT vendors, to learn advanced technology and management, and give $f$ ull play to its own characteristics, do complement each other [7]; At the same time, the domestic IT enterprises should also strengthen cooperation with the international financial industry and IT solution providers. In foreign markets, rely on international IT enterprises' service experience and customer network, to help Chinese IT companies to get a package of IT products 
and service solutions; Meanwhile, India, Ireland and other countries who rely on outsourcing of Europe and the United States are facing great difficulties due to the impact of the international financial crisis. On one hand, the domestic IT companies should actively catch up with the enterprises in India and Ireland on company size and pro fitability, on the other hand, good preparation should be prepared to do mergers and acquisitions in India, Irish's software outsourcing business[8]. Accelerate our own global business deployment speed and expansion speed.

Fifth, in the risk investment market, Chinese IT enterprises need "stable", "accurate", "cruel", not only reduce the blindness investment, but als o increase the support of original IT products; continues to focus on the development frontier of domestic IT industry, and enhance the IT management and the capacity of risk prevent, also need to maintain the coo peration with banks and other institutions in order to ensure cap ital safety; Our IT enterprises' selection of risk investment project should lay particular emphasis on IT industry, to encourage the development of new products. Continue to increase the funds of core technology and talents, improve the core competitiveness of the enterprise's brand, integrate our own advantage resources effectively, optimize product structure, further strengthen the expansion efforts of domestic market, promote brand internationalization strategy, so that enter the international market successfully8].

\section{CONCLUSION}

From the cu rrent view, the influence of the financial crisis that began in the 2008 is far from over. The financial crisis spread to the whole world, and China is not able to possess. All walks of life are displayed weakness on economic. The economic index declines significantly. The financial crisis storm inevitably spread to the real economy, and transmission to the entire IT industry chain. Generally speaking, although the financial crisis $h$ as impacted the global investment and consumers' confidence, but to China's IT pattern, the influence is much smaller. For our IT enterprises, this crisis brings no $t$ only threats bu $t$ also opportunities. In contrast, the opportunities are greater than the threats. Because the differences of China's IT products and the consumption structural of Chinese IT industry, so the United States financial crisis will only affect Chinese IT enterprise's performance in a short term, it will not hinder the ascension of China's IT industry for a lon $g$ time. Because China's IT industry has not reached the most highend market, so the impact of the Chi nese IT enterprise is comparatively small. If deal properly, it can be a good times to invest and start one's own business. IT enterprises of our country should actively grasp market opportunities by using this time when western I $\mathrm{T}$ giants fell into a trough, to control cost, gather talents, looking for $m$ erger and acquisition opportunities and overseas listing time, making Chinese IT enterprises rise up in the international market.
[1] WANG Qian. Mechanism and Path of IT-Driven Business Model Innovation. Chinese Journal of Management, Jan.2011, Vol.8 No.1: $126 \sim 132$

[2] Ye Chunsen, Liang Changyong, Chen Rong. Growth Mechanism of IT Service Outsourcing Enterprises. Forum on Science and Technology in China, 2011.9, (9): 81 86

[3] CUI Xiao-feng. Influence and Strategy of Global Financial Crisis to Bengbu IT Industry. SHANGYE JINGJI. No.7,2009: 22 24

[4] Zhang Jing. Brief Talks about the U. S. Financial Crisis and I ts Influence on Chines e IT Industry. TONG MEI KEJI. 2009.6, (2): 30 31

[5] HU Yu-yue. Risk Management of Chinese Enterprises in the Po stcrisis Era. JOURNAL OF Z HEJIANG GONGSHANG UNIVERSITY. Jan. 2010, No. 1 Vol. 100: 82 88

[6] Wang Gui Sen. RESEARCH ON RISK CONTROL MODEL OF ENTERPRISE'S IT SERVICE OUTSOURCING. Ph D Thesis. Harbin: Harbin Institute of Technology, March, 2011

[7] Liu Zhuguang. The Influence of Financial Crisis for Chinese Enterprise Overseas Merger and its Strategic Choice [J], Inquiry into Economic Issues, 210.1

[8] OSTERWALDER A, YVES P, CHIRSTOPHER L T. Clarifying Business Models: Origins, Present, and Future of the Concept[J].Communications of the Information Systems, 2005,15(5):1 25

\section{REFERENCES}

